\title{
The impact of oil price shocks on selected Kazakhstan's macroeconomic indicators
}

\author{
Erjan Akhmedov \\ Doctoral School for Management and Organizational Science, \\ Kaposvar University, Hungary \\ akhmedov.erjan@ke.bu
}

\begin{abstract}
This article studies the correlation between world oil prices and the selected Kazakhstan's macroeconomic variables using the method of vector autoregression (VAR). As expected, the macroeconomic variables under consideration demonstrate a significant correlation with oil price fluctuations. However, the results of the research show a certain discrepancy with the earlier researches, which considered previous negative oil price shock of 2008 in the form of quicker reaction to such shocks. This means that the dependence of Kazakh economy on oil price fluctuations increased since the previous oil price plunge $^{1}$. In this regard, it is worth pointing out that none of these researches targeted the relationship between oil prices and Kazakh macro-economy after June 2014, when the last oil price shock began. Another important result is the timeframe during which the influence of oil price shocks is actually significant. These results are important for understanding the processes happening in the economies of Kazakhstan and other oil-exporting countries.
\end{abstract}

Keywords: oil price shock, macroeconomic time series, Kazakhstan, VAR.

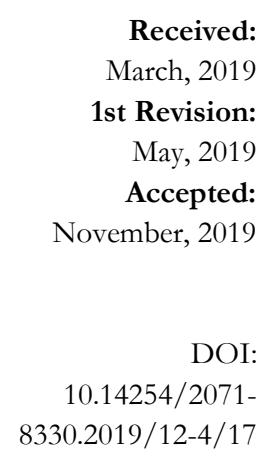

Received:

March, 2019

1st Revision:

May, 2019

Accepted:

November, 2019

DOI:

$10.14254 / 2071$ $8330.2019 / 12-4 / 17$

JEL Classification: C32, E17, E32, Q43.

\section{INTRODUCTION}

Earlier scientific papers have found serious dependence of main macroeconomic variables of oilexporting countries on oil price fluctuations. The focus of the current research is to investigate how these variables react to oil price movements in Kazakhstan's economic environment. The table below serves a good illustration of how economies of the biggest oil exporters reacted to the last two oil price plunges. The rest of the article studies the situation in Kazakhstan while considering it as a typical oil-exporting country.

\footnotetext{
${ }^{1}$ Words "plunge" and "negative oil shock" are used interchangeably throughout this article.
} 
GDPs of the biggest oil exporters before and after the last two oil price plunges, US\$

\begin{tabular}{|c|l|c|c|c|c|c|c|}
\hline No & Country & $\begin{array}{c}\text { GDP in } \\
\mathbf{2 0 0 8}\end{array}$ & $\begin{array}{c}\text { GDP in } \\
\mathbf{2 0 0 9}\end{array}$ & $\begin{array}{c}\mathbf{\%} \text { of } \\
\text { change }\end{array}$ & $\begin{array}{c}\text { GDP in } \\
\mathbf{2 0 1 4}\end{array}$ & $\begin{array}{c}\text { GDP in } \\
\mathbf{2 0 1 6}\end{array}$ & $\begin{array}{c}\text { \% of } \\
\text { change }\end{array}$ \\
\hline 1 & Saudi Arabia & 520 & 429 & $-17.4 \%$ & 756.6 & 645 & $-14.8 \%$ \\
\hline 2 & Russia & 1661 & 1223 & $-26.4 \%$ & 2064 & 1285 & $-37.7 \%$ \\
\hline 3 & Iraq & 132 & 112 & $-15.1 \%$ & 235 & 172 & $-26.9 \%$ \\
\hline 4 & United Arab Emirates & 316 & 254 & $-19.7 \%$ & 403 & 357 & $-11.4 \%$ \\
\hline 5 & Canada & 1549 & 1371 & $-11.5 \%$ & 1799 & 1536 & $-14.6 \%$ \\
\hline 6 & Nigeria & 208 & 169.5 & $-18.5 \%$ & 568.5 & 405 & $-28.8 \%$ \\
\hline 7 & Kuwait & 147 & 106 & $-28.2 \%$ & 162.6 & 111 & $-31.8 \%$ \\
\hline 8 & Angola & 84 & 76 & $-10.3 \%$ & 127 & 95 & $-24.8 \%$ \\
\hline 9 & Kazakhstan & 133 & 115 & $-13.6 \%$ & 221.4 & 137 & $-38.0 \%$ \\
\hline 10 & Norway & 463 & 387 & $-16.4 \%$ & 499.3 & 371 & $-25.7 \%$ \\
\hline
\end{tabular}

Source: Own construction based on the World Bank data ${ }^{2}$

From 2008 to 2009 the oil price (Brent) decreased by 36.6\% and from 2014 to 2016 -- by $55.8 \%$. The author selected the years 2008 and 2009, 2014 and 2016 as the years of beginning and end of the last two oil price shocks.

The key research question of this article is how oil price shocks affect the selected Kazakhstan's macroeconomic variables. This question deserves due attention because, in spite of the significance of oil in the economy of this country, which is one of the biggest oil exporters, the number of empirical researches on the effect of oil price shocks on Kazakh economy is still scarce. And, as it has been already mentioned in the abstract, none of the earlier studies have investigated the influence of oil price shocks on Kazakh macroeconomic variables after June 2014, when the last oil price shock began.

\section{LITERATURE REVIEW}

The influence of oil price shocks on macroeconomic variables has been extensively studied by different scientists because, as rightly mentioned by (Baumeister \& Kilian, 2016a), "The reason why economists care about oil price shocks is that these shocks affect economic decisions". Considering these sources, we should start with the seminal work of (Hamilton, 1983). This paper was the first to address the relationship between oil price shocks and US economic recessions and stimulated serious interest and discussions among scientists worldwide. For example, (Mork, 1989) noticed that the Hamilton's "study pertained to a period in which all the large oil price movements were upward, and thus it left unanswered the question whether the correlation persists in periods of price decline. Moreover, the price variable he used was somewhat distorted by price controls in the 1970s." So Mork's "note investigates whether Hamilton's results continue to hold when the sample is extended to include the recent oil market collapse and the oil price variable is corrected for the effects of price controls." Hamilton continued his scientific research and did a lot to increase our understanding of "the historical correlation between oil shocks and recessions" in this (Hamilton, 1996) and other scientific papers.

It is worth mentioning other influential papers, which have expanded our knowledge about the causes and effects of oil price shocks, the role of price variability and other serious topics. For example, (Lee, Ni,

\footnotetext{
2 https://data.worldbank.org/indicator/NY.GDP.MKTP.CD
} 
\& Ratti, 1995) argued "that an oil price change is likely to have greater impact on real GNP in an environment where oil prices have been stable, than in an environment where oil price movement has been frequent and erratic." (Allsopp \& Fattouh, 2011) focused "on issues surrounding international oil markets within the wider context of international energy, the global economy, and conflicting agendas such as energy security and climate change. It is suggested that important aspects of the current situation appear 'unsustainable' - increasing uncertainty and raising methodological difficulties for any assessment of likely future developments." (Segal, 2011) "examines the impact of oil price shocks and attempts to explain why the rise in oil prices up to 2008 had little impact on the world economy. It makes three main arguments. First, that oil prices have never been as important as is popularly thought. Second, that the most important route through which oil prices affect output is monetary policy: when oil prices pass through to core inflation, monetary authorities raise interest rates, slowing growth... The third argument is that high oil prices have not reduced growth in recent years because they no longer pass through to core inflation, so the monetary tightening previously seen in response to high oil prices is absent. It also argues that oil prices had little impact on the global recession of 2008-9". (Kilian, 2014) noted that "the real price of oil is endogenous with respect to economic fundamentals and that oil price shocks do not occur ceteris paribus, making it necessary to account for the deeper structural shocks underlying oil price shocks when studying their transmission to the domestic economy". (Baffes, 2015) are of the view that "The decline in oil prices has significant macroeconomic, financial and policy implications. If sustained, it will support growth and reduce inflationary, external, and fiscal pressures in a large number of oil-importing countries. On the other hand, sharply lower oil prices will weaken fiscal and external positions and reduce economic activity in a few oilexporting countries." Such prominent authors as (Bernanke, Gertler, Watson, \& Sims, 1997) increased our understanding of the role of monetary policy in postwar U. S. business cycles. Having examined over 40 years of data, (Difiglio, 2014) revealed that „oil price shocks are invariably followed by 2-3 years of weak economic growth and weak economic growth is almost always preceded by an oil price shock." (Van Robays, 2016) showed that ,higher macroeconomic uncertainty causes higher oil price volatility. Oil market dynamics are found to differ when uncertainty in the global economy is elevated as oil prices become more reactive to changes in oil demand and supply. This effect is statistically and economically significant as the reaction of oil prices following a similar change in oil supply or demand might easily double when it hits the economy in uncertain". Other serious contributions into this field of knowledge include (Ferderer, 1996), (Finn, 2000), (Ebrahim, Inderwildi \& King, 2014) and (van de Ven \& Fouquet, 2017).

For obvious reasons, the developed oil-importing countries like the USA, China, Japan, Germany, etc. received overwhelmingly more attention. However, more and more scientists address the dependence between oil price shocks and dynamics of macroeconomic indicators in oil-exporting countries. For instance, (Eltony \& Al-Awadi, 2001) examined "the impact of oil price fluctuations on seven key macroeconomic variables for the Kuwaiti economy". (Mehrara \& Oskoui, 2007) considered the sources (with oil price shocks being one of them) of macroeconomic fluctuations in such countries through the examples of Iran, Saudi Arabia, Kuwait, and Indonesia. (Korhonen \& Mehrotra, 2009) assessed "the effects of oil price shocks on real exchange rate and output in four large energy-producing countries: Iran, Kazakhstan, Venezuela, and Russia." (El Anshasy \& Bradley, 2012) empirically investigated the role that oil prices play in determining fiscal policy in oil-exporting countries. (Pomfret, 2012) analysed "resource management experiences of seven resource-rich Asian transition economies" having among other countries Azerbaijan and Kazakhstan as examples. (Hou, Mountain, \& Wu, 2016) used the example of Canada to study how oil price shocks affect an oil-exporting economy. (Cunado, Jo, \& Perez de Gracia, 2015) investigated macroeconomic effects of oil price shocks in Asian economies. (Mohn, 2016) looked at the "the relationship between household saving and government saving in Norway" though this country represents a completely different case when comparing with other oil-exporting countries. 
An interesting though controversial observation was made by (Rafiq, Sgro, \& Apergis, 2016) that "a decline in oil prices is beneficial to oil exporters due to the quantity effect outweighing the price effect, while for oil importers a stable oil price is more desirable than a price decline. These results are important to take into account if we are to gain a full understanding on the magnitude of the trade and macroeconomic effects of oil price changes and what the policy responses should be."

As mentioned above, the amount of such literature is substantially smaller than the one for oilimporting countries. However, there is a growing number of scientific publications exploring this subject including the works of (Mehrara, 2008), (Gronwald, Mayr, \& Orazbayev, 2009), (Alikhanov \& Taylor, 2015), (Basnet \& Upadhyaya, 2015), (Nurmakhanova, 2016), (Dikkaya \& Veli Doyar, 2017), (Ybrayev, 2017), etc. Their findings can be summarized as follows:

- (Mehrara, 2008): "output growth is adversely affected by the negative oil shocks, while oil booms or the positive oil shocks play a limited role in stimulating economic growth.";

- (Gronwald, Mayr, \& Orazbayev, 2009): "all variables under consideration in the VAR model GDP, inflation, budget revenue, exports, and the real exchange rate - exhibit a significantly negative response to oil price declines";

- (Dikkaya \& Veli Doyar, 2017): "we decide that there are unidirectional causalities running from oil prices to GDP, from exchange rate to GDP and oil prices to exchange rate for Kazakhstan.";

- (Nurmakhanova, 2016): "From the economic policy perspective, Kazakhstan should continue to decrease its dependency on energy prices in the longer run through reform policies."

Understandably, not very many literature sources address the period after the beginning of the last oil price plunge (after June 2014). However, the number of such papers is growing and we should mention the works of (Aastveit, Bjørnland, \& Thorsrud, 2015), (Baffes, 2015), (Verleger, 2015), (Baumeister \& Kilian, 2016b), (Kitous et al., 2016), (Aleksandrova, 2016), etc. One of the first such attempts was the article by (Tokic, 2015), which "suggests that the 2014 oil price collapse was possibly triggered by the falling Euro versus the US Dollar... The key argument presented in this article is that, as long as there are temporary economic growth divergences between the US and the EU, the resulting exchange rate volatility is likely to create the pricing inefficiencies in crude oil, which in fact are mean-reverting, as the economic growth divergences eventually dissipate." Describing global implications of lower oil prices (Husain et al., 2015) advise that "oil exporters will need fiscal adjustments, with their magnitude and pace varying according to the size of buffers (fiscal vulnerability)." An interesting paper was published by (Vandyck et al., 2018) who estimated "the macroeconomic impacts of a $60 \%$ oil price drop for all regions in the world." They also reflected "on the broader implications (such as migration flows) of macroeconomic responses to oil prices and look ahead to the challenge of structural change in a world committed to limiting global warming." Unfortunately the number of scientific papers devoted to oil-importing countries is substantially bigger than the number devoted to oil-exporting ones. This article is an attempt to close this gap.

\section{METHODOLOGY}

\subsection{Data}

This paper studies how oil price changes influence such macroeconomic variables as inflation, government revenues and exports. Choosing these variables the author intended to compare his results with the earlier researches, in particular with the results obtained by (Gronwald et al., 2009) who also considered the same macroeconomic variables. Even though many authors of similar articles consider the influence of oil price shocks on exchange rate, this is not possible for Kazakhstan where the exchange rate regime is often conditioned by political considerations. 
The author abstained from considering bigger number of macroeconomic variables because they require longer time series, which are not available. Also, the author wanted to avoid collinearity of the variables under consideration.

The following four variables were selected:

1. OP - Crude oil price (Brent), US\$/barrel;

2. CPI - Consumer price index used as a measure of Inflation;

3. GR - Government revenues, Kazakhstan tenge million (national currency);

4. E-Exports, US\$ million.

Data on consumer price index, government revenues and exports were obtained from the Statistics Committee of Kazakhstan web-site and data on Brent crude oil price were obtained from the Bloomberg markets web-site.

Quarterly data from the beginning of 2003 till the end of 2017 are used in this research. The author did not consider earlier data because the country joined the IMF's Special Data Dissemination Standard (SDDS) in 2003 and to achieve this Kazakhstan had to amend some of its statistics methodologies.

All variables presented in logarithmic form. Time series plot of these variables is shown on Figure 1 below.

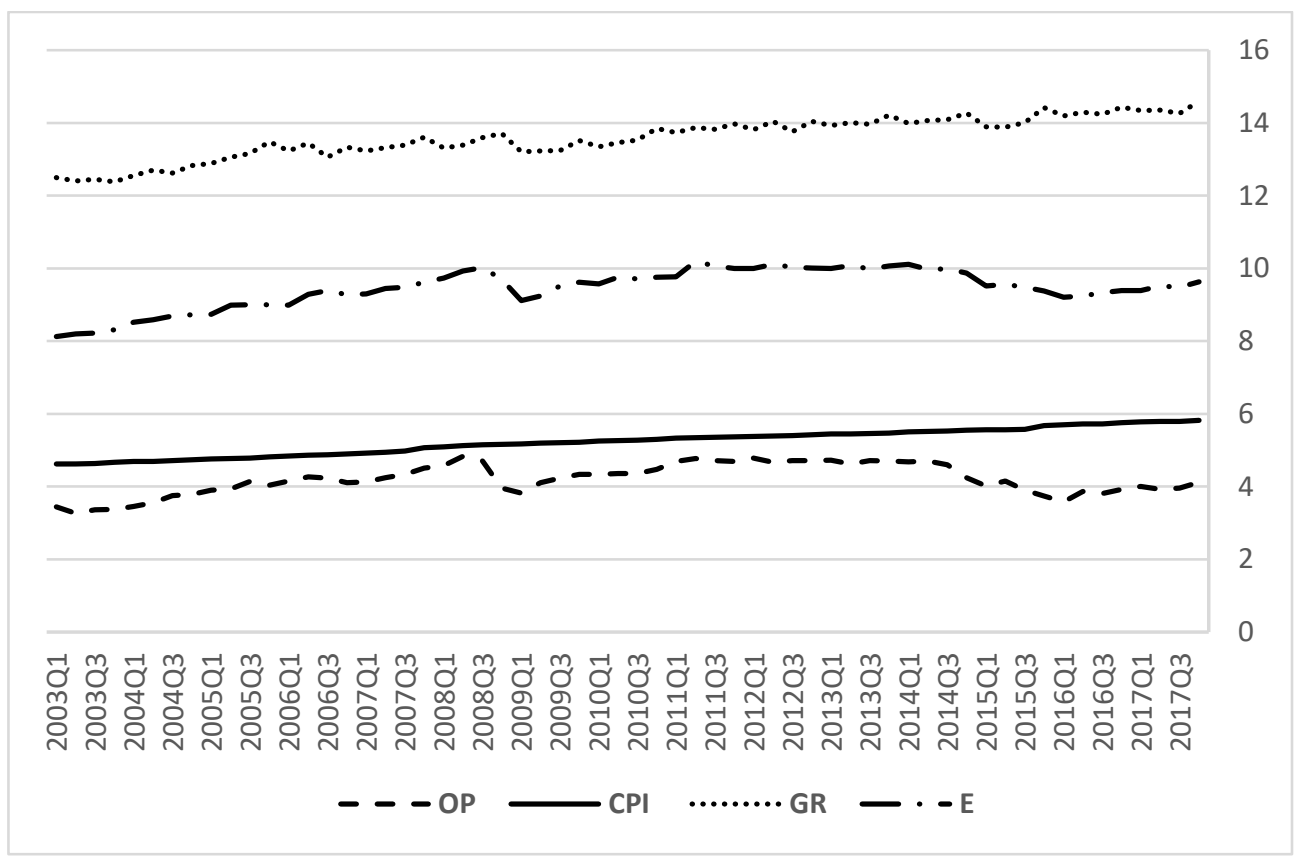

Figure 1. Time series plot

Source: Own construction based on Statistics Committee of Kazakhstan and Bloomberg markets data

\subsection{Research methods}

Since the seminal work by (Sims, 1980) vector autoregressive models, in which all variables are considered as endogenous, have become one of the main instrument in macroeconomic studies. The relevant literature considers VAR as one of the best models for studying the relationship between oil prices and macroeconomic variables in oil-exporting countries, and, as mentioned in the Literature review above, numerous authors applied VAR models for studying consequences of oil price shocks. The same model is usually employed for investigating the effect of oil price shocks on the economy of Kazakhstan and is applied in this article. 
The foundation of the VAR model presented in this article is based on the classic research on the relationship between oil prices and macroeconomic indicators. The VAR theory is well known and omitted here for brevity.

Tests and explanations below demonstrate that the selected method as well as the data used are acceptable for the purpose of the present article.

\subsubsection{Unit root test}

Estimation of the VAR parameters requires the time series to be covariance stationary. ADF (Augmented Dickey Fuller) test was applied to check stationarity.

The author started the test from 10 lags using Akaike information criterion.

Table 2

Results of the ADF unit root test

\begin{tabular}{|l|c|c|c|c|c|c|c|}
\hline \multicolumn{4}{|c|}{ Level } & \multicolumn{4}{c|}{ First order difference } \\
\hline Variables & Lag & t-statistic & P-value & Variables & Lag & t-statistic & P-value \\
\hline OP & 1 & -2.72672 & 0.06946 & d_OP & 1 & -5.67315 & 7.031 e-007 \\
\hline CPI & 0 & -0.337332 & 0.9124 & d_CPI & 0 & -6.41104 & $8.046 \mathrm{e}-007$ \\
\hline GR & 5 & -1.79982 & 0.3811 & d_GR & 6 & -3.77656 & 0.003171 \\
\hline E & 1 & -2.58435 & 0.1019 & d_E & 1 & -5.81966 & $3.213 \mathrm{e}-007$ \\
\hline
\end{tabular}

Source: own calculation

d_ - first order difference operator

The test shows that the selected time series become stationary in the first difference form, which will be used further.

\subsubsection{Selection of lag}

Three different lags of orders 8,4 and 2 were tested using different information criteria. The lag order 4 demonstrated the best values and was finally selected. It is worth mentioning that the lag order 4 is normally recommended for quarterly data.

\subsubsection{Estimating the VAR}

Initial estimation

Below are the excerpts from the VAR estimation:

VAR system (lag order 4)

OLS (Ordinary least squares) estimates of observations 2004:2-2017:4 $(\mathrm{T}=55)$

Log-likelihood $=315.13556$

Determinant of covariance matrix $=1.2396981 \mathrm{e}-010$

AIC $=-8.9867$

$\mathrm{BIC}=-6.5050$

$\mathrm{HQC}=-8.0270$

Portmanteau test: $\mathrm{LB}(13)=158.882, \mathrm{df}=144[0.1874]$ 


\subsubsection{Tests}

Table 3

Test for autocorrelation, order up to 4

\begin{tabular}{|c|c|c|c|}
\hline & Rao F & Approx. dist. & p-value \\
\hline $\operatorname{lag}$ 1 & 1.289 & $\mathrm{~F}(16,95)$ & 0.2205 \\
\hline $\operatorname{lag}$ 2 & 0.790 & $\mathrm{~F}(32,101)$ & 0.7744 \\
\hline $\operatorname{lag} 3$ & 0.744 & $\mathrm{~F}(48,90)$ & 0.8688 \\
\hline $\operatorname{lag} 4$ & 0.715 & $\mathrm{~F}(64,76)$ & 0.9155 \\
\hline
\end{tabular}

Source: own calculation

The author could not reject the null-hypothesis of no autocorrelation as p-value exceeds $5 \%$ for all lags. The absence of autocorrelation indicates that the estimators are consistent as the data are independently distributed.

Table 4

ARCH Test, order up to 4

\begin{tabular}{|c|c|c|c|}
\hline & LM & Df & p-value \\
\hline lag 1 & 106.285 & 100 & 0.3148 \\
\hline $\operatorname{lag} 2$ & 195.222 & 200 & 0.5822 \\
\hline $\operatorname{lag} 3$ & 297.222 & 300 & 0.5345 \\
\hline $\operatorname{lag} 4$ & 414.208 & 400 & 0.3015 \\
\hline
\end{tabular}

Source: own calculation

The null hypothesis is that there is no ARCH (autoregressive conditional heteroskedasticity) effect present. The author could not reject the null hypothesis at 10\%. The absence of ARCH effect implies conditional homoscedasticity.

Table 5

Normality of residuals test

Residual correlation matrix, C (4 x 4)

\begin{tabular}{|c|c|c|c|}
\hline 1 & 0.20733 & -0.056653 & 0.65909 \\
\hline 0.20733 & 1 & 0.41409 & 0.15420 \\
\hline-0.056653 & 0.41409 & 1 & -0.073443 \\
\hline 0.65909 & 0.15420 & -0.073443 & 1 \\
\hline
\end{tabular}

Source: own calculation

Eigen values of $\mathrm{C}$

0.338

0.533395

1.37772

1.75089

Doornik-Hansen test

Chi-square $(8)=24.2703[0.0021]$

The Doornik-Hansen test gives the p-value less than 5\%. This result indicates that this VAR is not normally distributed. To understand where the problem is, there is a need to test the normality of residuals 
for each series. Based on the results received, the author rejected the normality of residuals for the Inflation equation as having the $\mathrm{p}$-value less than $5 \%$.

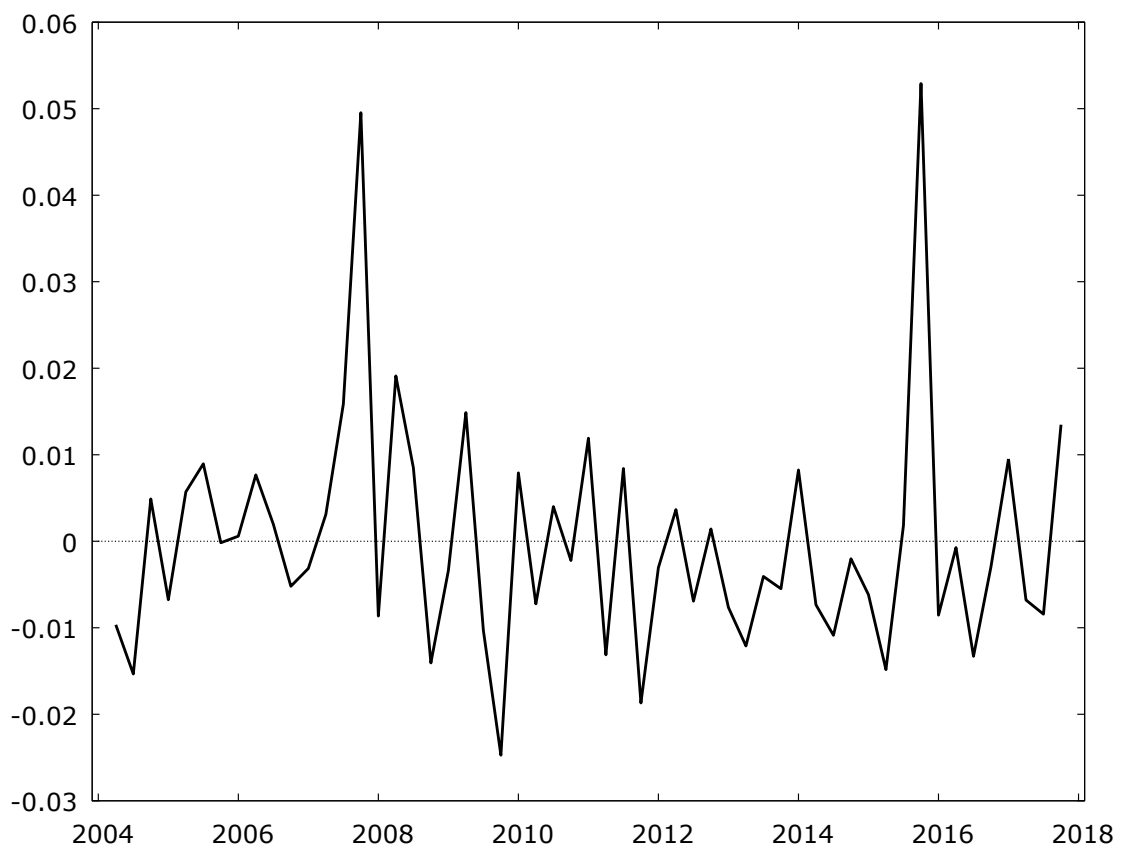

Figure 2. Residuals plot for the Inflation equation

Source: Own construction

The inclusion of two dummy variables corresponding to the outliers of 4th quarter 2007 and 4th quarters 2015 makes this VAR normally distributed. Now it can be presented as follows:

VAR system (lag order 4)

OLS estimates, observations 2004:2-2017:4 ( $\mathrm{T}=55)$

Log-likelihood $=360.18589$

Determinant of covariance matrix $=2.4091136 \mathrm{e}-011$

$\mathrm{AIC}=-10.3340$

$\mathrm{BIC}=-7.5603$

$\mathrm{HQC}=-9.2614$

Portmanteau test: $\mathrm{LB}(13)=182.283, \mathrm{df}=144[0.0170]$

Worth pointing out that these two outliers correspond to the crisis on the Kazakh real estate market of the second half of 2007 and the introduction of the freely floating exchange rate regime in Kazakhstan in August 2015.

This VAR also passes autocorrelation and ARCH tests.

\subsubsection{Asymmetry of oil price shocks and the application of structural VAR approaches}

Even though both approaches widely applied in similar researches, the author decided not to employ them in this article because of the following:

- $\quad$ The already mentioned (Korhonen \& Mehrotra, 2009) reported that "we are not able to reject the null hypothesis of linearity for Iran, Kazakhstan or Russia." (Nurmakhanova, 
2016) who studied this situation pointed out that their work was "The only study that tested whether the impact of oil prices on economic activity of Kazakhstan". The author of this article was not able to find such studies either.

- (Gronwald et al., 2009) found that "a standard linear VAR model is appropriate for capturing the Kazakh oil-macro relationship." Also, in Table 1 above, Kazakhstan demonstrated the highest GDP decrease from 2014 to 2016. This is a very strong sign of high dependency of the Kazakh economy on oil price fluctuations.

\section{EMPIRICAL RESULTS AND DISCUSSION}

\subsection{Impulse response functions}

Impulse responses of macroeconomic indicators to oil price shocks are given on plots below and clearly demonstrate the dependence of macroeconomic variables under consideration on oil price fluctuations.

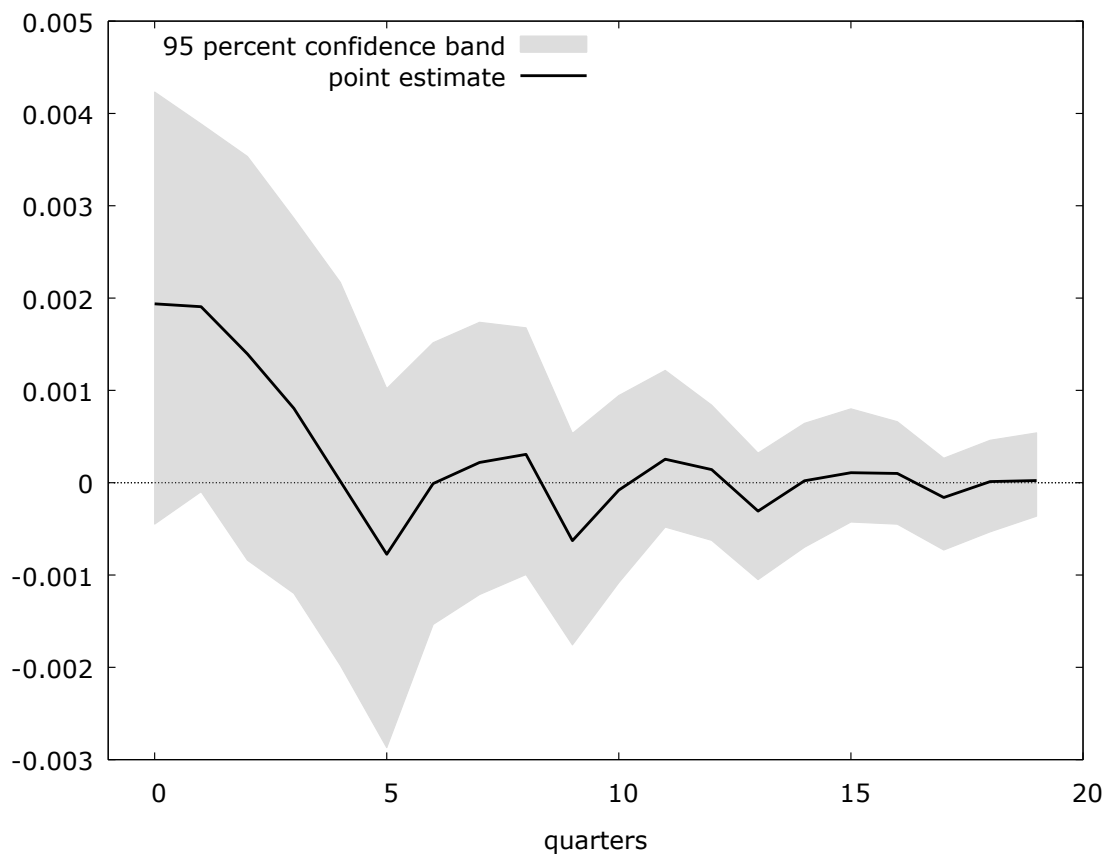

Figure 3. Impulse response: Inflation to a shock in oil price Source: Own construction

The peak of impact of an oil price shock on inflation remains high during the 1 st and the beginning of the $2^{\text {nd }}$ quarter and a relaxation emerges after about 5 quarters. The results of (Gronwald et al., 2009) are different. They reported that "the peak emerges after 3 quarters and it vanishes after about 8 quarters already." This means that after 2009 the dependence of inflation on oil price movements in Kazakhstan became even bigger. 


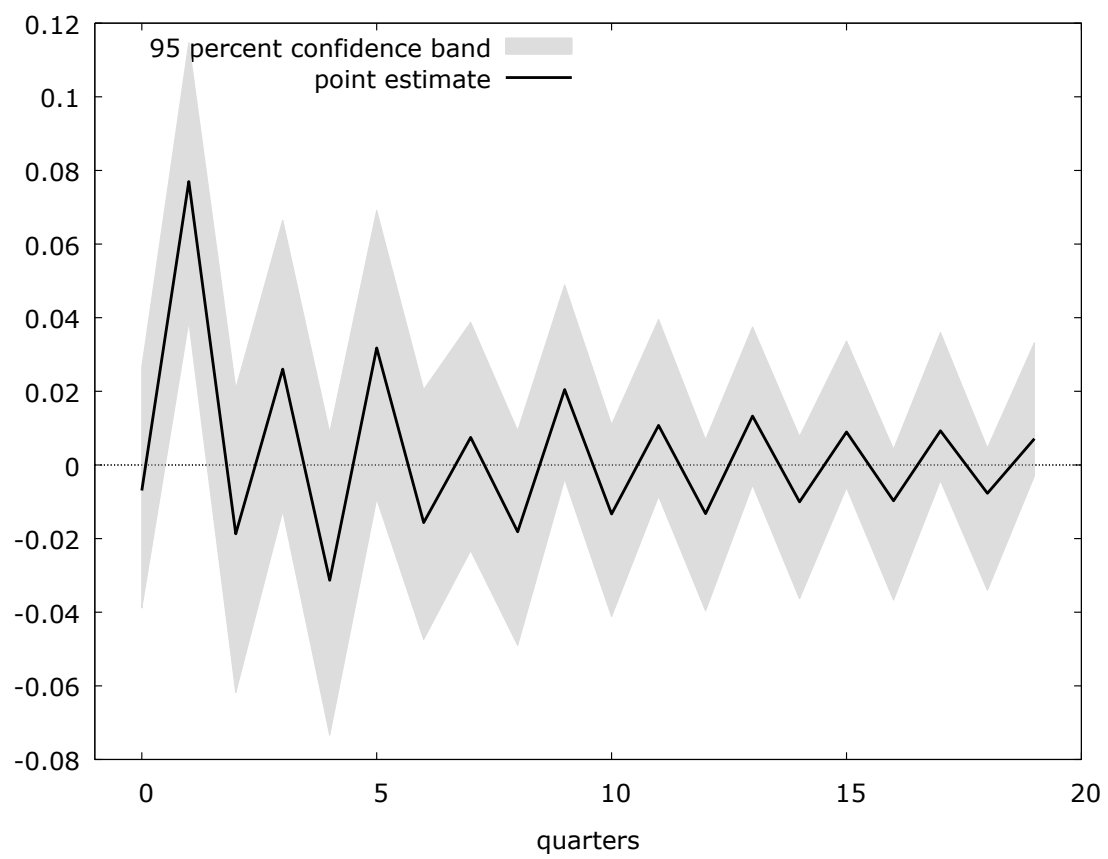

Figure 4. Impulse response: Government revenues to a shock in oil price Source: Own construction

The impact of an oil price shock on government revenues reaches its peak during the $1^{\text {st }}$ quarter, remains substantial until the $5^{\text {th }}$ quarter and decreases soon after. (Gronwald et al., 2009) reported somewhat different situation $\left(3^{\text {rd }}\right.$ and $5^{\text {th }}$ quarters respectively). This is another confirmation of the increased dependency of the Kazakh economy on oil price fluctuations.

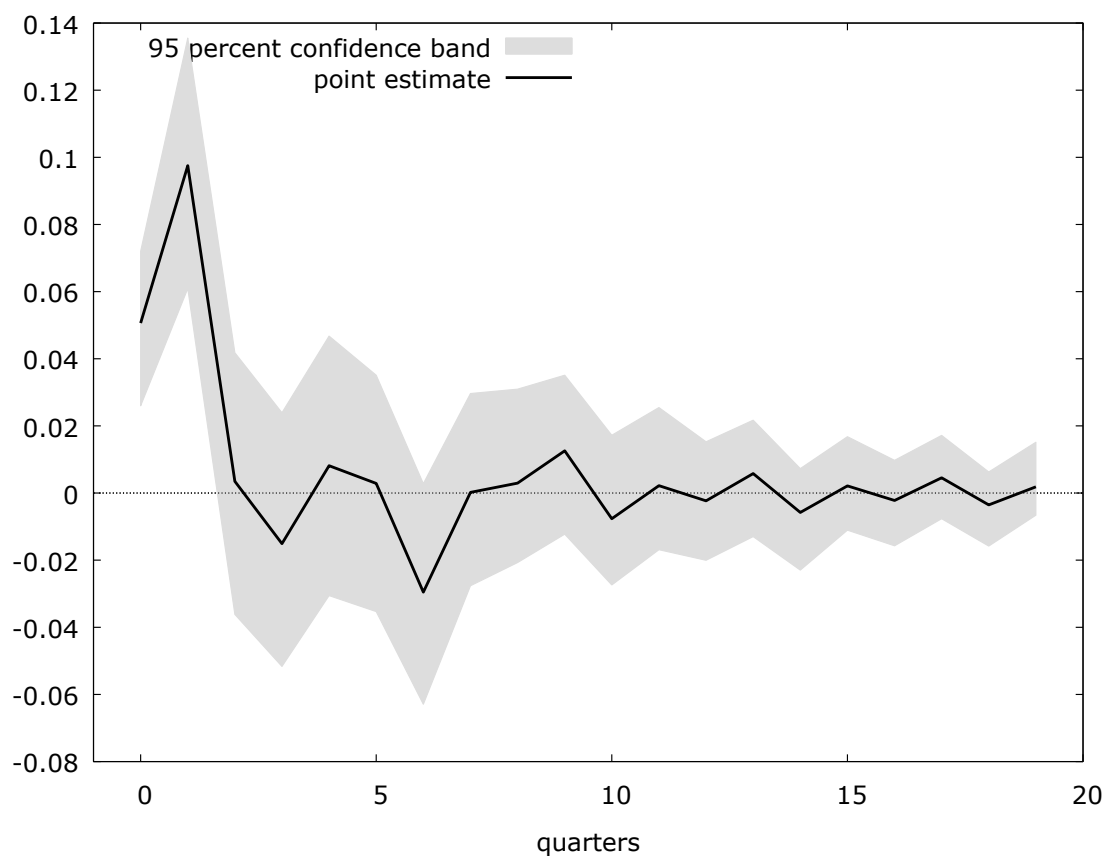

Figure 5. Impulse response: Exports to a shock in oil price

Source: Own construction 
The plot above demonstrates how oil prices and exports are correlated. Again the picture is very close to the reported by (Gronwald et al., 2009) who found that "a 10\% decline in prices leads to about $6 \%$ decline in exports". For the time period considered in the present article this decline is equal to $5 \%$.

\subsection{Variance decomposition}

The results of the forecast error variance decomposition show the proportion of the changes in a variable due to its own shocks versus shocks to the other variables. These results are shown in Attachment 1.

The results once again demonstrate how essential the role of oil in the Kazakh economy is. Interestingly, inflation is the most isolated from the oil price fluctuations. This is happening because until mid-2015 the Kazakh government was controlling inflation keeping it within a certain limit. However, since August 2015 when the Kazakh government introduced the freely floating exchange rate regime, inflation grew rapidly from $4.38 \%$ in the $3^{\text {rd }}$ quarter of 2015 to $13.53 \%$ in the $4^{\text {th }}$ quarter of the same year and remained high (from 15\% to 17\%) till the $4^{\text {th }}$ quarter of 2016. The year of 2017 demonstrated the downward trend with inflation going down to $7.1 \%$. For the other macroeconomic variables under consideration the role of oil price fluctuations is also very substantial.

The influence of government revenues on inflation is also noticeable, which in case of Kazakhstan is a sign of pro-cyclical fiscal policy. High budget revenues take place during economic expansion. At the same time, in the Kazakhstan's environment economic expansion itself causes inflation. Again, in the Kazakhstan's environment, high budget revenues loose the fiscal regime and this in turn further overheats the economy. This approach to the fiscal regime makes the government budget unbalanced when its revenues decrease.

The oil price was high during 2011-2013 period, which resulted in unprecedented levels of government revenues. However, the government continued to withdraw sizeable amounts from the National Oil Fund (\$9.2 billion per annum), which accelerated inflation during that period. And when the oil prices dropped, the government faced primary deficits over 10\% of GDP (2015-2016).

\section{CONCLUSION}

The presented research is important because of two main considerations:

- As mentioned above, the oil-importing countries like the USA, China, Japan, Germany, etc. receive overwhelmingly more attention in comparison with oil-exporting ones:

- This research is one of very few, which studies the influence of oil price shocks on the Kazakh economy and the first research, which considers this influence of oil price shocks on the Kazakh economy after the last oil price plunge, which started in June 2014.

Therefore, this article is trying to fill these two significant gaps in our knowledge.

Even though the main results described in this article generally support earlier researches on the same subject. However, there is a certain discrepancy with them. As in the earlier researches, the macroeconomic variables under consideration demonstrated significant correlation with oil price fluctuations, but the main difference with these researches is that the dependence of the Kazakh economy on oil price fluctuations substantially increased since the previous oil price plunge of 2008. Specifically, it is demonstrated that for two variables under consideration, namely inflation and government revenues, the peak of impact of an oil price shock on these variables takes place quicker than before. There is no substantial difference for exports, but this is easily explained by the big share of oil in Kazakh exports.

Another important result is the timeframe during which the influence of oil price shocks is actually significant. This result has important implications for the Kazakh government planning purposes. Actually 
not only Kazakh because the economic situations in such oil-exporting neighbours of Kazakhstan as Azerbaijan and Russia are very similar.

These results corroborate the need to decrease the dependence of oil-exporting countries on oil price fluctuations. Among the ways to achieve this goal, are such measures as stringent counter-cyclical economic policies and economic diversification.

Kazakhstan and other oil-exporting countries. The author is planning to continue studying this subject and to undertake a comparison of how several oil-exporting countries react to oil price shocks.

\section{ACKNOWLEDGEMENT}

I would like to express my sincere thanks and deep appreciation to my scientific supervisor Professor Dr. Konrad Wetzker and Dr. György Kövér from the University of Kaposvár.

This research received no specific grant from any funding agency in the public, commercial, or notfor-profit sectors.

\section{REFERENCES}

Aastveit, K. A., Bjørnland, H. C., \& Thorsrud, L. A. (2015). What Drives Oil Prices? Emerging Versus Developed Economies. Journal of Applied Econometrics, 30(7), 1013-1028. https://doi.org/10.1002/jae.2406

Aleksandrova, S. (2016). Impact of Oil Prices on Oil Exporting Countries in the Caucasus and Central Asia. Economic Alternatives, (4), 447-460. Retrieved from http://www.unwe.bg/uploads/Alternatives/S_A_2016_Issue4_en5.pdf

Alikhanov, M., \& Taylor, L. (2015). Real or nominal shock - which one does more to destabilize developing economies? The case of money velocity in Kazakhstan. Bulgarian Economic Papers (Www.Bep.Bg), (BEP 06- 2015). Retrieved from https://ideas.repec.org/p/sko/wpaper/bep-2015-06.html

Allsopp, C., \& Fattouh, B. (2011). Oil and international energy. Oxford Review of Economic Policy, 27(1), 1-32. https://doi.org/10.1093/oxrep/grr010

Baffes, J. et al. (2015). The Great Plunge in Oil Prices: Causes, Consequences, and Policy Responses (No. 23/2015). Canberra. https://doi.org/http://dx.doi.org/10.2139/ssrn.2624398

Basnet, H. C., \& Upadhyaya, K. P. (2015). Impact of oil price shocks on output, inflation and the real exchange rate: evidence from selected ASEAN countries. Applied Economics, 47(29), 3078-3091. https://doi.org/10.1080/00036846.2015.1011322

Baumeister, C., \& Kilian, L. (2016a). Forty Years of Oil Price Fluctuations: Why the Price of Oil May Still Surprise Us. Journal of Economic Perspectives, 30(1), 139-160. https://doi.org/10.1257/jep.30.1.139

Baumeister, C., \& Kilian, L. (2016b). Understanding the Decline in the Price of Oil since June 2014. Journal of the Association of Environmental and Resource Economists, 3(1), 131-158. https://doi.org/10.1086/684160

Bernanke, B. S., Gertler, M., Watson, M., \& Sims, C. A. (1997). Systematic Monetary Policy and the Effects of Oil Price Shocks. Brookings Papers on Economic Activity, (1), 91-157. Retrieved from http://www.jstor.org/stable/2534702

Cunado, J., Jo, S., \& Perez de Gracia, F. (2015). Macroeconomic impacts of oil price shocks in Asian economies. Energy Policy, 86, 867-879. https://doi.org/10.1016/J.ENPOL.2015.05.004

Difiglio, C. (2014). Oil, economic growth and strategic petroleum stocks. Energy Strategy Reviens, 5. https://doi.org/10.1016/j.est.2014.10.004

Dikkaya, M., \& Veli Doyar, B. (2017). Causality Among Oil Prices, GDP and Exchange Rate: Evidence from Azerbaijan and Kazakhstan. Journal of Social Sciences of the Turkic World, (83), 79-98. Retrieved from http://bilig.yesevi.edu.tr/yonetim/icerik/makaleler/2090-published.pdf

Ebrahim, Z., Inderwildi, O. R., \& King, D. A. (2014). Macroeconomic impacts of oil price volatility: Mitigation and resilience. Frontiers in Energy. https://doi.org/10.1007/s11708-014-0303-0

El Anshasy, A. A., \& Bradley, M. D. (2012). Oil prices and the fiscal policy response in oil-exporting countries. Journal of Policy Modeling, 34(5), 605-620. https://doi.org/10.1016/J.JPOLMOD.2011.08.021 
Eltony, M. N., \& Al- Awadi, M. (2001). Oil Price Fluctuations and their Impact on the Macroeconomic Variables of Kuwait: A Case Study Using a VAR Model. International Journal of Energy Research, (25(11)), 939-959. https://doi.org/10.1002/er.731

Ferderer, J. P. (1996). Oil price volatility and the macroeconomy. Journal of Macroeconomics, 18(1), 1-26. https://doi.org/10.1016/S0164-0704(96)80001-2

Finn, M. G. (2000). Perfect Competition and the Effects of Energy Price Increases on Economic Activity. Journal of Money, Credit and Banking, 32(3), 400. https://doi.org/10.2307/2601172

Gronwald, M., Mayr, J., \& Orazbayev, S. (2009). Estimating the effects of oil price shocks on the Kazakh economy (No. 81). Munich. Retrieved from http://hdl.handle.net/10419/73844

Hamilton, J. D. (1983). Oil and the Macroeconomy since World War II. Journal of Political Economy, 91(2), $228-248$. https://doi.org/10.1086/261140

Hamilton, J. D. (1996). This is what happened to the oil price-macroeconomy relationship. Journal of Monetary Economics, 38(2), 215-220. https://doi.org/10.1016/S0304-3932(96)01282-2

Hou, K., Mountain, D. C., \& Wu, T. (2016). Oil price shocks and their transmission mechanism in an oil-exporting economy: A VAR analysis informed by a DSGE model. Journal of International Money and Finance, 68, 21-49. https://doi.org/10.1016/J.JIMONFIN.2016.05.004

Husain, A. M., Arezki, R., Breuer, P., Haksar, V., Helbling, T., Medas, P., ... Team, S. (2015). Global Implications of Lower Oil Prices. IMF Staff Discussion Note (Vol. 15). Washington, DC. Retrieved from https://www.imf.org/external/pubs/ft/sdn/2015/sdn1515.pdf

Jiménez-Rodríguez, R., \& Sánchez, M. (2005). Oil price shocks and real GDP growth: empirical evidence for some OECD countries. Applied Economics, 37(2), 201-228. https://doi.org/10.1080/0003684042000281561

Kilian, L. (2014). Oil Price Shocks: Causes and Consequences. Annual Review of Resource Economics, 6(1), $133-154$. https://doi.org/10.1146/annurev-resource-083013-114701

Kitous, A., Saveyn, B., Keramidas, K., Vandyck, T., Santos, L. R. L., \& Wojtowicz, K. (2016). Impact of low oil prices on oil exporting countries. Joint Research Centre Science for Policy Report, European Commission (Vol. JRC101562). Sevilla. https://doi.org/10.2791/718384

Korhonen, I., \& Mehrotra, A. N. (2009). Real Exchange Rate, Output and Oil: Case of Four Large Energy Producers. SSRN Electronic Journal, 6. https:// doi.org/10.2139/ssrn.1428238

Lardic, S., \& Mignon, V. (2008). Oil prices and economic activity: An asymmetric cointegration approach. Energy Economics, 30(3), 847-855. https://doi.org/10.1016/J.ENECO.2006.10.010

Lee, K., Ni, S., \& Ratti, R. A. (1995). Oil Shocks and the Macroeconomy: The Role of Price Variability. The Energy Journal, 16(4), 39-56. https://doi.org/10.2307/41322616

Lutkepohl, H., \& Kratzig, M. (2004). Applied Time Series Econometrics. Cambridge: Cambridge University Press. https://doi.org/10.1017/CBO9780511606885

Mehrara, M. (2008). The asymmetric relationship between oil revenues and economic activities: The case of oilexporting countries. Energy Policy, 36(3), 1164-1168. https://doi.org/10.1016/J.ENPOL.2007.11.004

Mehrara, M., \& Oskoui, K. N. (2007). The sources of macroeconomic fluctuations in oil exporting countries: A comparative study. Economic Modelling, 24(3), 365-379. https://doi.org/10.1016/J.ECONMOD.2006.08.005

Mohn, K. (2016). Resource revenue management and wealth neutrality in Norway. Energy Policy, 96, 446-457. https://doi.org/10.1016/J.ENPOL.2016.06.026

Mork, K. A. (1989). Oil and the Macroeconomy When Prices Go Up and Down: An Extension of Hamilton's Results. Journal of Political Economy, 97(3), 740-744. https://doi.org/10.1086/261625

Moshiri, S., \& Banihashem, A. (2012). Asymmetric Effects of Oil Price Shocks on Economic Growth of Oil-Exporting Countries (USAEE Working Paper No. 12-140). SSRN Electronic Journal. https://doi.org/10.2139/ssrn.2163306

Nurmakhanova, M. (2016). Oil and Growth Challenge in Kazakbstan (Working Paper No. E16/06). Retrieved from eercnetwork.com/default/.../a5ca0f48eeaa2062a0564249a96832b75c658f86.pdf\%0A

Patrick Ekong, N., \& Wilson Ebong, ---Daniel. (2016). ON THE CRUDE OIL PRICE, STOCK MARKET MOVEMENT AND ECONOMIC GROWTH NEXUS IN NIGERIA EVIDENCE FROM COINTEGRATION AND VAR ANALYSIS Contribution/ Originality. Asian Journal of Economic Modelling, 4(3), 112-123. https://doi.org/10.18488/journal.8/2016.4.3/8.3.112.123 
Pomfret, R. (2012). Resource management and transition in Central Asia, Azerbaijan and Mongolia. Journal of Asian Economics, 23(2), 146-156. https://doi.org/10.1016/J.ASIECO.2011.08.004

Rafiq, S., Sgro, P., \& Apergis, N. (2016). Asymmetric oil shocks and external balances of major oil exporting and importing countries. Energy Economics, 56, 42-50. https://doi.org/10.1016/J.ENECO.2016.02.019

Segal, P. (2011). Oil price shocks and the macroeconomy. Oxford Review of Economic Policy, 27(1), 169-185. https://doi.org/10.1093/oxrep/grr001

Sims, C. A. (1980). Macroeconomics and Reality. Econometrica, 48(1), 1. https://doi.org/10.2307/1912017

Tokic, D. (2015). The 2014 oil bust: Causes and consequences. Energy Policy, 85, $162-169$. https://doi.org/10.1016/J.ENPOL.2015.06.005

van de Ven, D. J., \& Fouquet, R. (2017). Historical energy price shocks and their changing effects on the economy. Energy Economics, 62, 204-216. https://doi.org/10.1016/j.eneco.2016.12.009

Van Robays, I. (2016). Macroeconomic Uncertainty and Oil Price Volatility. Oxford Bulletin of Economics and Statistics, 78(5). https://doi.org/10.1111/obes.12124

Vandyck, T., Kitous, A., Saveyn, B., Keramidas, K., Los Santos, L., Wojtowicz, K., ... Wojtowicz, K. (2018). Economic Exposure to Oil Price Shocks and the Fragility of Oil-Exporting Countries. Energies, 11(4), 827. https://doi.org/10.3390/en11040827

Verleger, P. (2015). Structure Matters: Oil Markets Enter the Adelman Era. The Energy Journal, Volume 36(Adelman Special Issue). https://doi.org/10.5547/01956574.36.SI1.pver

Ybrayev, Z. (2017). The prospect of inflation targeting in Kazakhstan. Eurasian Journal of Economics and Finance, 5(1), 33-48. Retrieved from https://ideas.repec.org/a/ejn/ejefjr/v5y2017i1p33-48.html 